\title{
Perceived Views of Language Teachers on the Use of Needs Analysis in ESP Materials Writing
}

\author{
Holi Ibrahim Holi Ali ${ }^{1} \&$ Abdel Rahman Abdalla Salih ${ }^{2}$ \\ ${ }^{1}$ School of Education \& Professional Development, University of Huddersfield, UK \\ ${ }^{2}$ Department of English Language and Literature, Al-Zahra College for Women, Muscat \\ Correspondence: Holi Ibrahim Holi Ali, PhD Student of Applied Linguistics \& TESOL, School of Education \& \\ Professional Development, University of Huddersfield, UK. Tel: 96-892-295-223. E-mail: howlli2@yahoo.com
}

Received: December 23, $2012 \quad$ Accepted: January 6, $2013 \quad$ Online Published: February 1, 2013
$\begin{aligned} & \text { doi:10.5539/elt.v6n3p11 } \quad \text { URL: http://dx.doi.org/10.5539/elt.v6n3p11 }\end{aligned}$

\begin{abstract}
Needs analysis is generally believed to be important in ESP/EAP context because it enables practitioners and materials writers to find out about their real learners' needs. Therefore, this study is set out to investigate EFL teachers' beliefs and views about need analysis use and practices, specifically in the ESP/EAP tertiary context of the Sultanate of Oman. A group of (55) EFL teachers in 4 colleges participated in the study by responding to a questionnaire designed for the study's purpose. The questionnaire was analyzed and percentages and frequencies were taken. The study concluded that needs analysis has to be encouraged and leaners' needs are of utmost importance ESP/EAP materials writing. The findings of this study showed that the vast majority of EFL teachers are in favour of using needs analysis as a basis for ESP/EAP materials writing and they believe that it is a significant factor in successful ESP materials development.
\end{abstract}

Keywords: needs analysis, ESP/EAP practice, material production, learner involvement

\section{Background}

English language teaching (ELT) is a progressive field that often witnesses revolutions and innovations. Teachers, researchers, and practitioners are in continuous search for the best teaching materials and practices that can help learners succeed in their language learning and meet the market and employment criteria. In the nineteenth century, language teaching practice for instance, grammar-translation method was in its heydays, notably in Europe. However, the changing geopolitical conditions and social scenes in the USA due to massive migrations, tourism, increasing internationalization of trade and business shaped the classroom practices in the early years of the twentieth century. The direct consequences of that have called for practicing new methods since grammar-translation method was no longer able to meet the new class reality. Such a new reality had its potential impact on classroom. This supported by Cook (2003) pointed out that "new types of students-immigrants, business people, and tourist created a new kind of classroom population" who their needs need to be considered (p. 33). From practical point of view grammar-translation method would not fit the new classroom scenes, challenges and the students' needs since 'in the language schools and evening classes which created for them, the students did not necessarily share the same first language, making it simply impossible for instruction to proceed through first-language explanation and translation" (ibid). The compelling urgency for language need by immigrants, businessmen and tourists for communication purposes motivated language experts to promote the 'direct method'. In an attempt to meet the students need for writing and speaking abilities in English and provide a supportive context for language practice and use, the students' first languages were abolished encouraging them to use the target language.

This significant move in response to the language learners' needs has been further motivated by the emergence of communicative language teaching method (CLT) which stressed on the significance of learners' knowledge of both language forms and their relevance to the context in which they are used. This has motivated the advocacy of exploring learners' needs, a crucial element of English for Specific Purposes (ESP), as argued by Cook (2003) that "whereas in the past, whether in grammar-translation or in direct method teaching, the emphasis had been upon mastery of forms first and their use later, CLT students considered first what they needed to do with the language and then learned the forms which would fulfill those needs" (pp. 36-7). Hutchinson \& Waters (1993) claim that designing an ESP course is fundamentally a matter of asking questions to the learners in order to 
provide areas and basis for subsequent process of syllabus design, material production, classroom teaching and evaluation (1993, p. 107). However, according to Kandil (2009) "needs analysis has not received sufficient attention from researchers in the Arab world. As a result, Arab learners rarely have input in their language teaching context" (p. 1) this fact is realized in the ESP practices in the Omani context.

\section{Review of Related Studies}

\subsection{Defining Needs Analysis}

Defining needs analysis is something that has generated controversy because linguists in the ESP field have not agreed yet on the definition of the term 'need' itself. Richard as cited in Al-Harby, (2005, pp. 15-16) argued that the definition of 'needs' depends on the perception of those making the judgment. Teachers, learners, administrators, employees, parents and stakeholders may have different views as to what 'needs' are. Needs analysis is defined by Nunan (1988) as an information gathering process when he referred to needs analysis as "techniques and procedures for collecting information to be used in syllabus design"(p. 13) Thus, needs analysis is a prerequisite for any ESP/ EAP course design to achieve effective and instructional outcomes and to deliver appropriate input. Further in Richards \& Platt, (1992, p. 242, cited in Al-Tamimi \& Shuib, 2007) needs analysis is defined as "the process of determining the needs for which a learner or group of learners require a language and arranging the needs according to priorities" (p. 1). Hutchinson \& Waters (1987) defined needs analysis by distinguishing between target needs, i.e. what the learner needs to do in order to learn, and 'wants' which represent the learners' views regarding what their needs are. Target needs; according to the authors include 'necessities' which refer to what the learner has to know in order to function effectively in the target situation. While, 'lacks' which refer to need to know what the learner knows already in order to decide which of the necessities the learner actually 'lacks' (pp. 54-56). It is observed that all the definitions have many things in common in a sense that they focused on the learners' needs as a source of information for designing syllabus or developing materials that fit the learners' actual needs.

\subsection{Why Needs Analysis?}

Needs analysis is recommended in English language teaching, in general, and in teaching ESP and EAP in particular. Richards and Nunan (1994) claimed that needs analysis serves many purposes in English language teaching as:

- It provides a means of obtaining a wider input into the content, design, and implementation of language programme.

- It can be used in developing and setting up goals, objectives and contents for programmes.

- It can provide data for reviewing and evaluation of existing programmes.

\subsection{Who Carries out the Needs Analysis?}

Mountford (1981) as cited in Al-Amin, (1999, p. 16) claimed that the question 'who carries out the needs analysis?' is one of three questions that represent methodological problems related to needs analysis. The other two issues are: the problem of principles (what should the analysis include and exclude as relevant content?), and the problem of practice (how should the analysis be undertaken and applied) (Robinson 1991: 10 in ibid, 16). For answering the question of who carries out needs analysis, Robinson, (1991) thought that for large institutions or companies an outside expert may be called and given a special status and thus gain access to sources of information closed to the insider. In contrast, the rationale of an outsider is to bring a fresh air of eyes to the situation and may be able to make impartial assessment of what is needed but it is argued that the insider analysts such as (teachers, administrators, etc.) are familiar with the target situation and the students' and employees' immediate needs and they can carry out the analysis effectively.

\subsection{Studies on Needs Analysis in the Arab World}

There is a plethora of research in needs analysis that has been undertaken locally, regionally and internationally in different disciplines with different frameworks. However, some key studies in the Arab world context have been reviewed and discussed in order to contextualize the present study.

Zoghoul \& Hussein (1985) carried out a study in Jordan on the language needs of undergraduate students from different disciplines such as natural sciences, engineering, medical sciences, economics, administrative sciences, and arts and humanities. The study examined the perceptions of both students and staff members. The findings indicated that the students overestimated their language abilities, whereas faculty members gave a more realistic assessment of students' capabilities. This study was also focused on language needs rather than other needs which are highly encouraged and considered by ESP models. The study was also confined to students' and staff's 
perceptions only rather than investigating their actual needs.

Remache (1992) conducted a study which aimed at diagnosing the English language competency and the communicative needs of postgraduate students studying in ESP centers in Algeria. It also attempted to identify the teaching and learning problems that the teachers and students encountered. Finally a proposal was developed for English for Specific purposes (ESP) course based on the findings of the study. A questionnaire was used to analyze language students' and language teachers' needs. The results were used to design an effective syllabus to be used in the all ESP centres. However, the study was limitedonly to communicative needs.As'Seyabi (1995) conducted a needs analysis study which aimed at identifying the students' perceptions regarding their English language- related needs and problems of science and science-education at Sultan Qaboos University (SQU). The participants' were 164 students, and 54 faculty members from Faculty of Science. The instruments used were observations, interviews and questionnaires. The findings indicted that science students perceived learning needs as the most problematic, followed by the communicative needs and lastly by linguistic needs. The faculty members, on the other hand, indicated that communicative needs were the most problematic, followed by linguistics and lastly by learning needs. The study suggested the need for evaluating the present ESP programme at SQU and solvingthedifficulty faced by the students. However, it neglected students' target and learning needs.

In the same context, Al-Busaidi (2003) conducted a needs analysis study to investigate the academic needs of EFL learners at Sultan Qaboos University (SQU) in the Sultanate of Oman. The study followed a triangulation approach for collecting data. The tools used were interviews, email dialogues, and questionnaires. The participants were college and language programme faculty members as well as undergraduate students at SQU. The study aimed to identify programme practices that were effective in meeting the learners' needs. The results showed that the students generally had mixed perceptions of the intensive programme. The findings indicated that there were some goals with the intensive progarmme's curriculum and learners' academic needs. The study suggested that in order to make the programme more effective and responsive to learners' needs, a hybrid content-based curriculum model must be used to integrate language and college courses. Also more cooperation was needed between the language center and subjects teachers in order to raise awareness about learners' needs. However, this was confined only to academic needs and it did not put into consideration students' learning and target needs.

Pritchard \& Nasr (2004) conducted a needs analysis study in an Egyptian College of Technology, to develop materials to help improve third-year engineering students' reading performance. A needs analysis was conducted to find out how students and teachers perceive major required reading skills. A reading programme was developed based on both teachers' and students' perceptions and needs. The programme was tested with a group of 66 students to evaluate its effectiveness. The results showed that the programme helped improve the students' reading capabilities. However, the study was centred only on the skill of reading, and there was no room for other skills. Methodologically, only a questionnaire was used to collect the data, and neither administrators nor teachers were involved in the investigation.

\subsection{ESP Teacher and ESP Learner}

The ESP teacher is fundamentally a language teacher and despite the multiplicity and diversity of roles, he/she must be viewed within the broad context of ELT pedagogy. Robinson (1991, p. 1) as cited in Yasin (1999) claimed that ESP teachers are "researchers, course designers, materials writers, testers, evaluators as well as classroom teachers" (p. 67). Moreover, Kennedy and Bolitho (1984, p. 138) offered the following list for the diverse role of an ESP practitioner:

1. Conducting needs analysis with or without support.

2. Based on the needs analysis, he is expected to design a syllabus.

3. He must be familiar with wide range of ESP materials to select.

4. Writing and exploiting materials.

5. Writing course outline and report to sponsors.

6. He may have to develop working knowledge of his students' subject and team-teach with subject teachers in an atmosphere of mutual trust and cooperation.

7. He may be required to teach EOP to a company and as a provider of service he needs to visit the company.

Having mentioned the diverse roles of the ESP practitioner, many challenges and problems are faced when running ESP classes. Hutchinson \& Waters (1993, p. 158), highlight three problems which face the ESP teacher, such as the interdisciplinary nature of ESP in which they need to be familiar with the students' subject 
knowledge. The second problem is the change of the role from a general English language teacher to ESP practitioner, and the final problem is that ESP is relatively new and it therefore, lacks traditions. Due to these factors an ESP teacher often needs to exert more effort to prepare more authentic materials and choose the suitable methodology to teaching.

ESP courses are usually based on learners' needs analysis which aims to specify as closely as possible what exactly it is that students have to do and how to do it through medium of English. Therefore, ESP leaners are usually aware of their needs and what they want and what they lack (Hutchinson \& Waters 1993), consequently, they have a high level of motivation for they see their ESP course directly relevant to their immediate communication and work place needs.

This is supported by Hutchinson\& Waters (1993: 53) "what distinguishes ESP from GPE is not the existence of a need as such but rather than an awareness of the learners' needs". Additionally, ESP learners are often believed to be adults or near adults. Robinson (1998: 2) noted that ESP has " a close association with adult learners or at least learners at the post -secondary level". This, of course, has the advantage that the ESP learners are likely to possess considerable a dormant competence in English that could be activated.

To summarize, literature from different contexts was reviewed and clustered into themes. Furthermore, some of the most important theoretical and contextual issues were addressed in order to put the study in perspective and set the ground for the whole thesis.

\section{Statement of the Problem}

English language teaching practice in the Sultanate of Oman at the tertiary level is gaining increasing significance and importance as a part of the emerging higher education activity. English language is taught as a subject in schools, but is widely used in colleges and universities in the country, a similar status the language enjoys in other states of the Arab world. As far as the Sultanate of Oman is concerned, graduates are expected to have good knowledge of English besides an excellent ability to speak and write in the language in order to qualify for a job. The private sector in particular gives greater priority to excellent command of English in addition to other qualifications and generic skills. The crux of the matter is that students join the degree programme with very weak performance in the English subject upon finishing higher secondary examination, and have to cope with completely different English syllabus and teaching strategies. The materials used may not be students'-needs directed. In other words, students' needs were not explored or analyzed in the process of selecting the materials used. There is a compelling necessity in Oman. Thus, needs analysis in the implementation of ESP-related syllabi is imperative in a sense that such an exercise enables learners to know what they are learning, for what purpose and the expected learning outcomes. This study advocates encouraging needs analysis in Oman and the Arab world and is motivated by exploring learners' needs to enable them to develop graduate attributes and academic skills as well.

\subsection{Research Questions}

1. What are the language teacher-respondents' perceptions of importance of needs analysis in ESP material writing?

2. What is the extent of the importance of need analysis in ESP material writing?

\section{Methods and Procedures}

This study is exploratory in nature in a sense that it investigates teachers' views on needs analysis practice in the higher education field in the Sultanate of Oman, focusing on perceptions rather than production, with the reliance on minimal statistical analysis. To achieve such a goal, a questionnaire (see Appendix A) was designed and distributed to total of (55) professional English teachers with varieties of teaching experiences in (4) colleges in the Sultanate of Oman.The participants and the colleges were chosen randomly on the basis of practical reasons and their convenience.

\subsection{Procedures}

This study employed one source of data: questionnaire surveys. The questionnaire was designed to explore the respondents' perceptions about the significance of needs analysis in ESP in the Sultanate of Oman in general and in their teaching context in particular. The questionnaire was also administered to examine the ESP practitioners' views on the value of involving learners and other concerned bodies in the material writing and production. Additionally, to guarantee reliability, the questionnaires were piloted before administration to iron the wrinkles out and a new version was drafted that was with clear instructions for the respondents. 


\section{Limitations of the Study}

The study does not investigate students' and labour market's views and perceptions about the significance and importance of needs analysis. In addition, the number of the participants was 55 teachers which might not be a representative sample and may limit the generalization of the findings.Finally; the study limits itself to the Sultanate of Oman only rather than other Gulf countries.

\section{Results and Discussion}

The questionnaire was designed to elicit the respondents' perceptions about the significance of needs analysis as a fundamentalstep in the production of effective ESP materials. The questionnaire sheets ( 55 sheets in 12 items) were collected and analysed to examine the respondents' views on needs analysis. The informants' responses to each item were calculated and the frequencies and percentages were analysed under the categories of 'needs analysis in Oman context', 'relevance of needs analysis in ESP material production in Oman (Fig.1)', 'significance of needs analysis (Fig.2)', and 'needs analysis and material development (Fig.3)'. The analysis revealed interesting findings as shown below.

When the respondents were asked about their views with regard to the significance of needs analysis in ESP materials in Oman (item1), the majority (46\%) reported that needs analysis is 'very important', with (9\%) indicating that it 'is somewhat important', while only (1\%) of the respondents viewed it as 'not too important'. Such a result suggested that needs analysis is highly appreciated by English teachers in the ESP context.

\subsection{Needs Analysis in Oman Context: Theory and Practice}

Items ( $7 \& 8)$ were designed to examine the degree of needs analysis implementation in ESP materials in the ESP teaching context in Oman. The analysis of item (7) revealed mixed responses as it showed that (48\%) 'agreed', and (35\%) 'disagreed' that needs analysis is used in their teaching context, while (17\%) 'disagreed' with the statement. On the other hand, the respondents' responses to item (8) showed that (22\%) 'agreed', (54\%) 'not sure' that learners' and labour market's needs are always investigated and incorporated in ESP materials production. For the same item (24\%) 'disagreed' with the statement. This result is interesting because it raises a number of issues pertaining to teacher awareness of needs analysis and the degree of involvement (if found) in the process. In addition, this finding accords with the issues addressed in Kandil (2009). It could be argued that raising teachers' awareness of the significance of needs analysis is a key step in any attempt for producing effective materials.

\subsection{Relevance of Needs Analysis in Oman}

In an attempt to explore teachers' views of the realisation of needs analysis in ESP practice in Oman context, the respondents' score was presented in Figure 1 below.

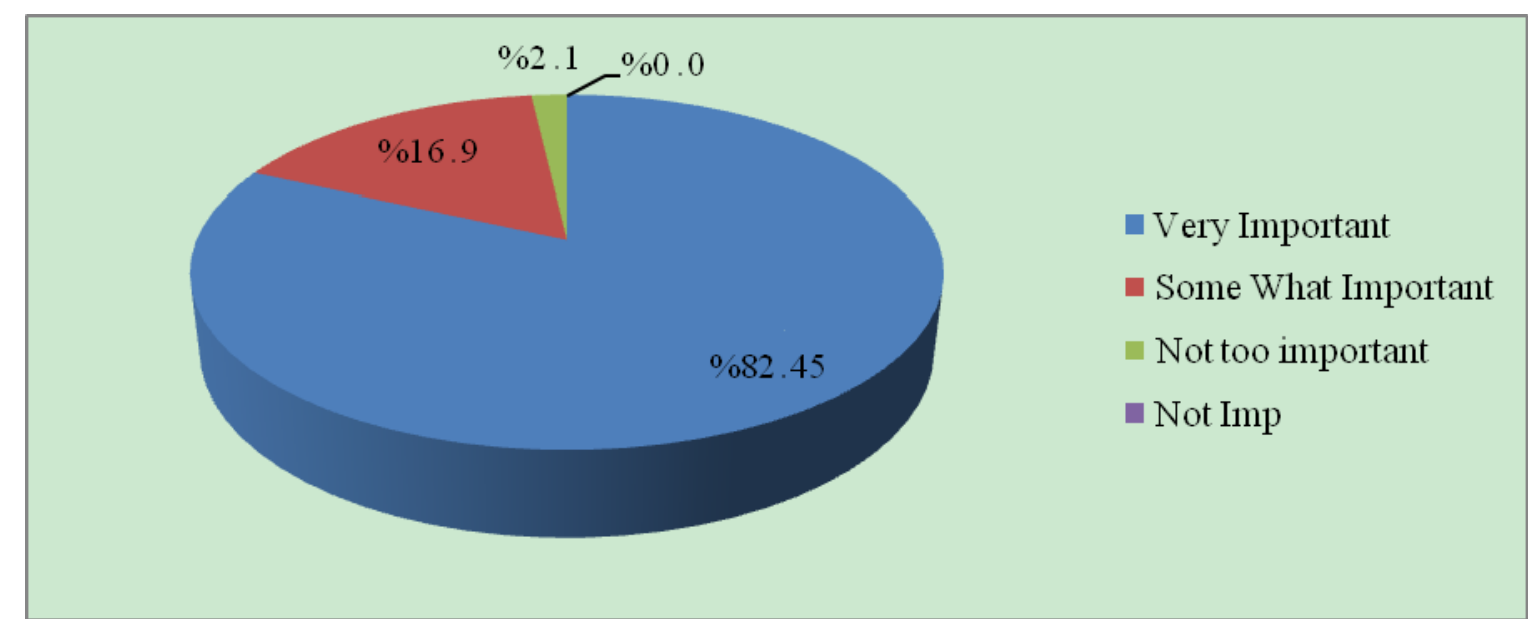

Figure 1. Relevance of needs analysis in ESP material production in Oman

Moreover, Figure 1 above reveals another interesting finding since none of the respondents viewed as of no significance for the ESP practice. It could be argued that teachers' expectations about needs analysis in ESP context should be encouraged and motivated to ensure that the learning outcomes match with the job market requirements and conditions. On the other hand, the respondents' perceptions about the significance of needs 
analysis were summarized in Figure 2 below.

\subsection{Importance of Needs Analysis}

Figure 2 below presents a summary of the respondents' score on the importance of needs analysis as a way of getting views of those concerned.

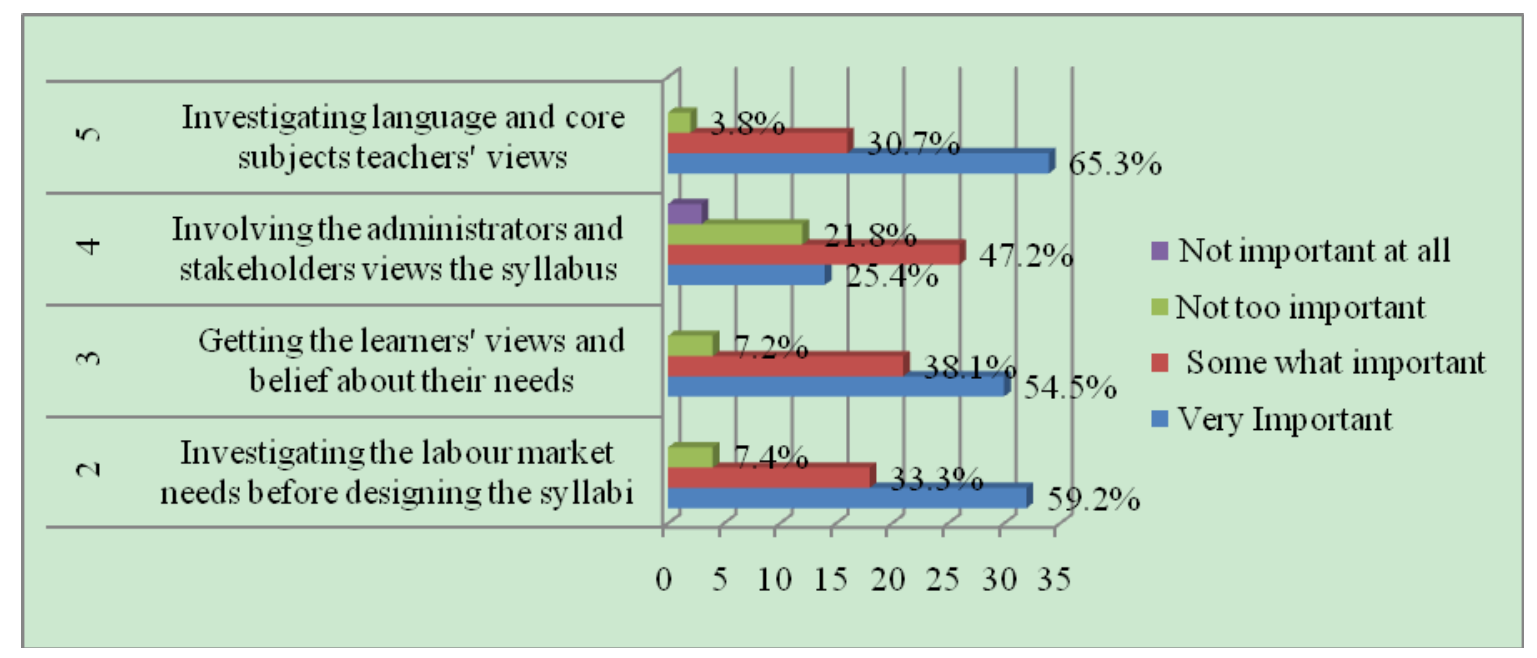

Figure 2. Significance of needs analysis

Item (2) in the questionnaire survey was about the value of investigating the labour market needs before designing any ESP course. In this context, the respondents were asked about whether they consider exploring the labour market needs as valuable for material development. The analysis revealed that (59\%), and (33\%) believed that investigating labour market needs is 'very important', and 'somewhat important' respectively before taking any step in designing ESP materials. On the other hand, (7.4\%) of the respondents believed that considering labour market needs is not important. This finding is consistent with the respondents' overwhelming support (item1) for the necessity of needs analysis process in general (Richards \&Nunan, 1994), and Oman in particular (Al-Busaidi, 2003). Item (3) was designed to investigate the teachers' perception on getting the learners' views and beliefs about their needs. The analysis revealed that (46\%), and (38\%) of the respondents believed that getting the learners' views on their needs is 'very important' and 'somewhat important' respectively. Only (7.2\%) believed that such a step is 'not too important'. This result suggests that teachers hold value for the learners' involvement in needs analysis process and material design practice (As'Seyabi, 1995). Teachers' perceptions about involving other concerned bodies were also explored. The analysis revealed that (25.4\%) believed that it is 'very important' to involve the administrators and stakeholders in the syllabus design process. On the other hand, (47.2\%) believed that it is 'somewhat important' to do so, while (22\%) believed that it is 'not too important' to involve administrators and stakeholders in the syllabus design. Less significantly, 3 respondents (1.5\%) reported that it is 'not important at all' to explore the administrators' and stakeholders' needs for syllabus design. This result revealed the fact that teachers were not fully supportive of involving the administrators and stakeholders in the material design process.

Item (5) in the questionnaire was designed to examine the teachers' views on investigating the views of language and core subjects' teachers as a part of syllabus design process. Interestingly, $(65 \%)$ believed it is 'very important', and (31\%) believed that it is 'somewhat important', while (4\%) saw it as 'not too important' to explore the views of language and core subjects teachers' for during designing ESP syllabus. It could be argued that encouraging needs analysis across the disciplines would enable ESP syllabus designers to provide suitable materials allowing for best teaching practices and quality learning as well. In other words, involving all key players within the learning and teaching setting is postulated to set the setting for effective learning capable of meeting the job market challenges and expectations.Thus, involving language teachers and other core subjects' teachers is expected to maximize the production of more authentic ESP syllabus and materials.

\subsection{Needs Analysis Process and Material Development}

Figure 3 below summaries the respondents' score on the significance of needs analysis for material development. 


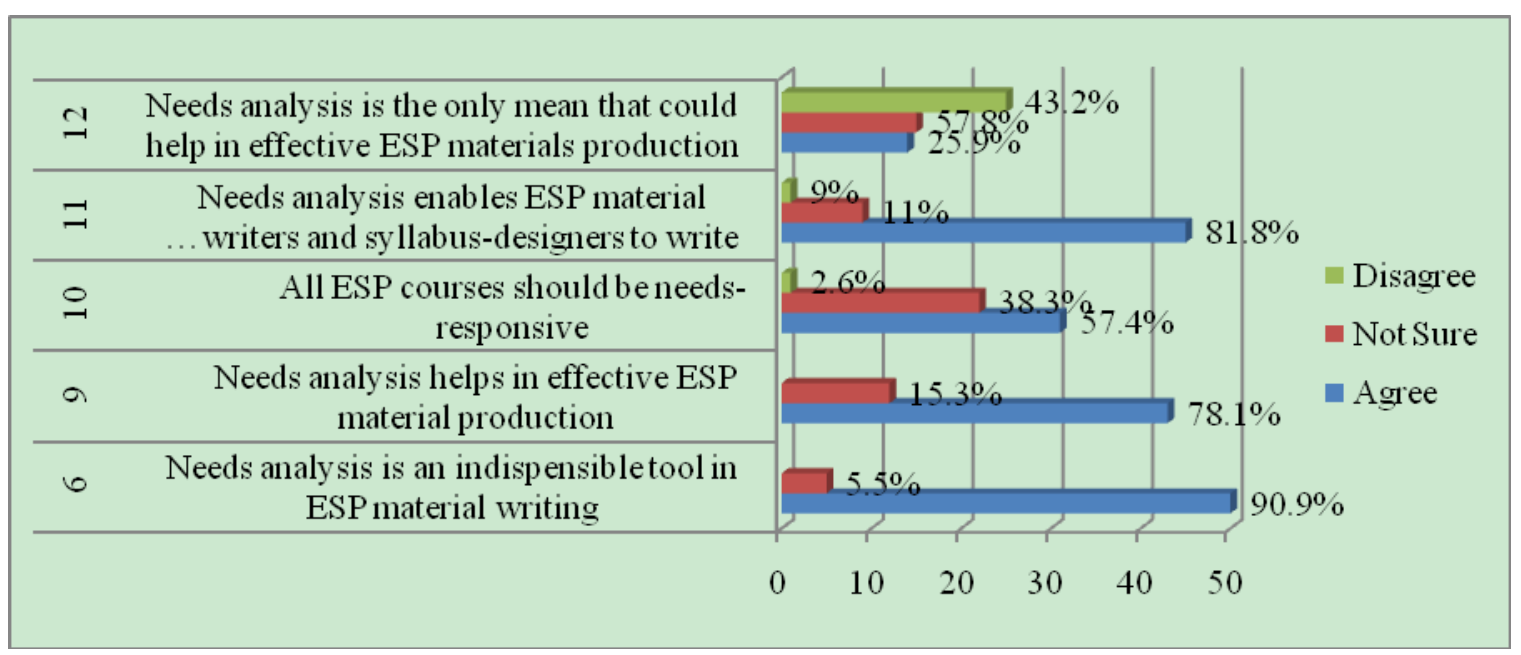

Figure 3. Needs analysis and materials development

The analysis of item (6) in the questionnaire revealed that (90\%) of the respondents 'agreed' that needs analysis is an integral part in ESP material writing, while $(6 \%)$ were 'not sure' of their stand. This interesting result revealed the fact that ESP teachers are aware of the necessity of needs analysis in ESP material writing process. In the same vein, the analysis of item (9) revealed a similar stand with (78\%) who 'agreed' that needs analysis helps in the production of effective ESP materials. Other respondents (15\%) were 'not sure' about their views. The analysis of item (10) revealed that (57\%) 'agreed', (3\%) 'disagreed', while (38\%) were 'not sure'that all ESP materials should be driven by needs analysis. It is worthy to note that the respondents showed mixed views about the idea that all ESP materials must be needs-responsive as a condition for their effectiveness. This might be interpreted as teachers' preference for more flexible materials and syllabi. Item (11) was designed to investigate teachers' views on the role of needs analysis in the ESP material writing. The analysis revealed a consistent result with the respondents' responses to items $(1,6, \&$ 9) as $(82 \%)$ 'agreed' that needs analysis enables the production of effective ESP materials, while (11\%) 'disagreed', and $(9 \%)$ were 'not sure'. The respondents' support for the role of needs analysis indicates the teachers' interest in more needs-driven materials. The analysis of item (12) revealed that (26\%) 'agreed', and (58\%) were 'not sure' that needs analysis is the only means that could help in producing effective ESP materials. On the other hand, $(43 \%)$ 'disagreed' with the statement, suggesting that alternatives other than needs analysis should be sought as well in designing ESP-based materials. This result contradicts with the respondents' supportive responses for needs analysis (items 1, 6, 9, \& 11). The respondents seem to hold two sides of views pertaining to the role needs analysis plays in the ESP practice.

\subsection{Extracts from Respondents' Comments}

The following are some comments made by some of the teachers who responded to the questionnaire.

T1: Needs analysis, while a vital tool, can be only effective if materials produced are small and confined to small groups. Repeated changes based on needs of students/industry can be sustained only with unlimited resources.

T2: Needsanalysis is definitely an important component of ESP material production. However, in reality, commercial books are used to fit into classroom teaching objectives. If needs analysis is done for a group of students, in-house supplementary materials should be produced by experienced teachers who are willing to 'think out of the box'.

T3: In the Omani context, I believe that there is more need for ESAP (English for Specific Academic Purposes) than ESP. It is very difficult for the language teacher to assess the needs/requirements of students in a discipline that he/she himself is not a specialist in (an outsider). Needs analysis is best left to the content teacher (the specialist in the field). Working in collaboration with the content teacher can guarantee that what we bring (material) to the class is relevant, at the right level of difficulty and can actually help them learn about their subject of specialization from the specialist (the content lecturer, not the language teacher). Thus, we need to be helping them with academic studies in their area of specialization, ESAP.

\section{Conclusion}

The study was an attempt to explore ESP practitioners' views on the significance of needs analysis in Oman in 
general and in the teachers' teaching context in particular. To serve its purpose, the study utilized the responses of 55 ESP teachers in 4 higher learning institutes in Oman to a questionnaire of 12 items. The respondents were also requested to make additional comments if they feel it is necessary to do so. The analysis of the questionnaire showed interesting results with regard to the issue under investigation. The findings were supportive of the literature which called for more needs-responsive ESP materials. Thus, there is an urgent need for considering needs analysis in ESP material production in the Arab world in general and Oman in particular. This may perhaps help in bridging the gap between learning outcomes and labour market 'frustration' over poor graduates' communicative skills. In this context, encouraging needs analysis is of significance for higher learning institutes aspirations to prepare qualified learners equipped with academic and non-academic skills. Moreover, ESP teachers need to hold consistent and clear understanding of needs analysis, partners to be involved and the significance of implementing it in their teaching context.

\section{References}

Al-Busaidi, S. S. (2003). Academic needs of EFL learners in the intensive English language program at Sultan Qaboos University in the Sultanate of Oman. Unpublished $\mathrm{PhD}$ thesis. University of Illinois at Urbana-Champaign, United States-Illinois.

Al-Harby, M. (2005). ESP Target situation needs analysis: The English language communicativeneeds as perceived by health professionals in the Riyadh area. Unpublished Ph.D. thesis. University of Georgia. $\begin{array}{lllll}\text { Retrieved on } & 16 & \text { April } & \text { 2011, }\end{array}$ http://faculty.ksu.edu.sa/majed/Documents/alharby_majid_200505_phd.pdf

As'seyabi, F. (1995). Identifying the English language needs of science students in the college of science and college of education and Islamic sciences at Sultan Qaboos University. Unpublished MA thesis. Sultan Qaboos University, Oman.

Al-Tamimi, A., \& Shuib, M. (n.d). Investigating the English Language needs of petroleum engineering students at Hadhramout University of Science and Technology.

Cook, G. (2003). Applied linguistics. Oxford: Oxford University Press.

Dudley-Evans, T. (2001). English for specific purposes. In Carter, R., \& Nunan, D. (Eds.), The Cambridge guide to teaching English to speakers of other languages (pp. 131-136). Cambridge: Cambridge University Press. http://dx.doi.org/10.1017/CBO9780511667206.020

Dudley-Evans, T., \& Maggie, S. T. (1998). Developments in English for Specific Purposes: A multi-disciplinary approach. Cambridge: Cambridge University Press

Hutchinson, \& Waters. (1993). English for specific purposes: A learning-centered approach. Cambridge: Cambridge University Press.

Hutchinson, \& Waters. (1997). Life lines intermediate English course. Oxford: Oxford University Press.

Hutchinson, \& Waters. (2011). How communicative is ESP? Retrieved on 13 April 2011, from http://eltj.oxfordjournals.org/content/38/2/108

Kandil, A. (2002). Needs analysis and the Arab learners. Retrieved on 11 May 2011, from http://ilearn.20m.com/ research/needs.htm

Kennedy, C., \& R. Bolitho. (1984). English for Specific Purpose. Hong Kong: Macmillan: Publisher LTD.

Pritchard, M., \& Nasr, A. (2004). Improving reading performance among Egyptian engineering students: Principles and practices. English for Specific Purposes, 23, 425-445. Retrieved on 8 June 2011, from http://dx.doi.org/10.1016/j.esp.2004.01.002

Remache, A, A. (1992). A needs analysis to ESP syllabus design with special reference to English for Science and Technology in Algerian ESP context. Unpublished PhD, University of Wales.

Robinson, P. (1993). English for Specific Purposes. Oxford: Oxford University Press.

Robinson, P. (1991). ESP today: A practitioner guide. London Prentice Hall.

Yasin, A. (1999). The need for ESP/EAP teacher training in Sudanese tertiary institutions post-Arabicization. Unpublished $\mathrm{PhD}$ thesis, University of Khartoum, Sudan.

Yin, M. K. (1988). ESP for engineers: a reassessment. ELT Journal, 42, 2102-108. Oxford. Retrieved on 11 May 2011, from http://eltj.oxfordjournals.org/content/42/2/102 
Zughoul, M., \& Hussein, R. (1985). English for higher education in the Arab world: A case study of needs analysis at Yarmouk University. The ESP Journal, 4, 133-152. http://dx.doi.org/10.1016/0272-2380 (85)90016-2

\section{Appendix A}

\section{Teachers' Questionnaire}

Dear colleagues, this questionnaire is meant to explore and examine your views about the use of needs analysis in ESP materials production in Oman. You are kindly requested to answer these questions honestly and objectively. You may be assured that your responses will be used for research purposes only and they will remain confidential.

\section{Very important $=4 \quad$ somewhat Important $=3 \quad$ Not too important $=2 \quad$ Not important at all $=1$}

\begin{tabular}{|c|c|c|c|c|c|}
\hline No & Statement & 4 & 3 & 2 & 1 \\
\hline 1. & Using needs analysis in ESP material production in Oman. & & & & \\
\hline 2. & Investigating the labour market needs before designing the syllabi. & & & & \\
\hline 3. & Getting the learners' views and belief about their needs. & & & & \\
\hline 4. & Involving the administrators and stakeholders in the syllabus design process. & & & & \\
\hline 5. & Investigating language and core subjects teachers' views. & & & & \\
\hline Not Sure $=2$ & Not Sure $=2$ & & & & \\
\hline 6. & Needs analysis is an indispensible tool in ESP material writing. & & & & \\
\hline 7. & Needs analysis is used in my teaching context. & & & & \\
\hline 8. & Students' and labour market's needs are always investigated and incorporated. & & & & \\
\hline 9. & Needs analysis helps in effective ESP material production. & & & & \\
\hline 10. & All ESP courses should be needs-responsive. & & & & \\
\hline 11. & Needs analysis enables ESP material writers and syllabus -designers to write effective materials. & & & & \\
\hline 12. & Needs analysis is the only mean that could help in effective ESP materials production. & & & & \\
\hline 13 & \multicolumn{5}{|l|}{ Any comments or suggestions? } \\
\hline
\end{tabular}

